\title{
Compressive Strength Properties of Geopolymers from Pond Ash and Possibility of Utilization as Synthetic Basalt
}

\author{
Byoungkwan Kim*, Bokyeong Lee ${ }^{* *}$, Chul-Min Chon $* * * *$, and Sujeong Lee $(\mathbb{D} * * * * * * ; *$ \\ *Resources Recycling, University of Science \& Technology, Daejeon 34113, Korea \\ **Intelligent Construction Automation Center, Kyungpook National University, Daegu 41566, Korea \\ ***Geological Environment Division, Korea Institute of Geoscience and Mineral Resources, Daejeon 34132, Korea \\ ****Mineral Resources Research Division, Korea Institute of Geoscience and Mineral Resources, Daejeon 34132, Korea
}

(Received May 31, 2019; Revised June 30, 2019; Accepted July 1, 2019)

\begin{abstract}
Pond ash is a mixture of mostly coarser fly ash and bottom ash. The recycling rate of pond ash is low because pond ash is mixed with seawater and deposited in ponds. The pond ash is also subjected to natural weathering over a period of time. In this study, we investigated whether pond ash can be used as a raw material of geopolymers, without any purification process or through a minimal purification process. In addition, we investigated whether synthetic basalt made by adding foaming agent to geopolymer or casting it into a mold can show the surface of the natural basalt as it is. The highest 7-day compressive strength in geopolymers from pond ash without purification process was $26 \mathrm{MPa}$. The highest 7-day compressive strength in geopolymers from pond ash with impurities removed through dry sieve analysis was found to improve to $80 \mathrm{MPa}$. On the other hand, synthetic basalt made with geopolymer was shown to be more advantageous aesthetically when produced by casting it in a silicone mold rather than by adding a foaming agent. Non-purified pond ash can be made into geopolymers having low strength. Pond ash purified by sieving can, without use of an aggregate, be made into geopolymer having high-strength. Also, it is possible to produce synthetic basalt with the same appearance as natural basalt and sufficient strength for commercialization. This process will contribute to the mass consumption and recycling of pond ash.
\end{abstract}

Key words : Geopolymer, Pond ash, Compressive strength, Synthetic basalt

\section{Introduction}

$\mathrm{T}$ he annual amount of coal ash generated in 2014 from Coal-fired Power Plants (CFPPs) was nearly 8.5 million tons or more, and the figure is expected to increase to 10 million tons or more by $2020 .{ }^{1)}$ Nearly $53 \%$ of the coal ash produced is recycled as ready-mixed concrete admixtures; $7 \%$, as supplementary materials for cement; $20 \%$, as fill aggregates; and the other $20 \%$ is delivered to ash treatment facilities located on coasts and disposed of in landfills. ${ }^{2)}$ Most of the ash treatment facilities in domestic CFPPs have now reached the saturation point. But extending or constructing new ash treatment facilities is less feasible due to concerns about the risk of soil and marine contamination resulting from the disposal of coal ash, as well as resistance from local residents. ${ }^{1,3)}$ Pond ash, which refers to ash submerged in seawater, is composed of reject ash which falls into the category of large-particle fly ash, and bottom ash. Pond ash has high unburned carbon content ${ }^{4)}$ and impurities, such as soil and seawater salt. Also, this type of ash is

Corresponding author: Sujeong Lee

E-mail : crystal2@kigam.re.kr

Tel : +82-42-868-3125 Fax : +82-42-868-3418

ORCID

https://orcid.org/0000-0001-8425-2878 weathered because it has been exposed to the air for a long period of time. Recent studies have indicated that some pond ash may contain heavy metals, but the content of such heavy metals does not exceed the harmful substance content limit under the Wastes Control Act. Having said that, pond ash is not frequently recycled due to the perception that heavy metals negatively affect the human body. ${ }^{1)}$

Thus far, several approaches have been proposed to recycle pond ash, for example, as lightweight aggregates, road fill materials, and backfill materials for structures. ${ }^{5,6)}$ Recently, there have also been studies on the manufacture of geopolymers by dry sieving and grinding pond ash with a caustic soda aqueous solution, used as an alkali activator. ${ }^{7-9)}$ It is worth noting that these studies used empirical formulation methods where the molar concentration of alkali activator was adjusted in various ways regardless of the mineralogical and chemical properties of the pond ash and the content of amorphous aluminosilicate materials that can react. ${ }^{7-9)}$ Manufacturing geopolymers based on empirical formulation methods may occasionally result in highstrength when strong alkali is used, but the quality of the fabricated geopolymers varies depending on the type of coal ash used, making the overall process less reproducible. Also, using a substantive amount of strong alkali may increase unit production costs and cause efflorescence. ${ }^{10,11)}$ Alternatively, a geopolymer can be fabricated by quantitatively 
evaluating the mineralogical and chemical properties of the coal ash and mixing it with an appropriate amount of alkali activator. When this has been attempted, the average 7-day compressive strength has reached $120 \mathrm{MPa}$, and the maximum compressive strength reached $140 \mathrm{MPa}$, while efflorescence was prevented..$^{10-12)}$

Meanwhile, coal ash-based geopolymers can be processed into lightweight porous geopolymers which resemble natural basalt in color and shape, by adding foaming agents to coal ash-based geopolymers. ${ }^{13)}$ Recently, there has been high domestic demand for natural basalt, which can be used to fabricate various products, such as landscaping stepping stones, boundary stone, and interior products, due to its excellent durability and appearance. Since December 2005, when natural basalt from Jeju Island was designated a resource to be preserved, its quarrying and exporting have been restricted. As a result, natural basalt materials have been imported from foreign countries, such as China and Vietnam. Meanwhile, there have also been studies on the manufacturing of synthetic basalt. For example, some researchers have attempted to do so by placing a compound that contained cement, water, coarse aggregates, fine aggregates, pigments, superplasticizers, etc. in a silicon mold with basalt texture and curing it at $65^{\circ} \mathrm{C} .{ }^{14)}$ In another study, a foaming agent was added to a compound of cement, basalt powder sludge, and pigments, and the compound was sintered at high temperatures, of over $1,100^{\circ} \mathrm{C} .^{15)}$ The synthetic basalt methods above, however, were not able to faithfully reproduce the color and texture of natural basalt.

This study aimed to assess the possibility of using pond ash, as it is or with the impurities removed, as a raw material for geopolymers. Also, the developed pond ash-based synthetic basalt was evaluated to determine if it faithfully reproduced the surface of natural basalt. The major findings of this study indicate that it is possible to fabricate highstrength geopolymers and a synthetic basalt that has the same appearance as natural basalt, as well as strength high enough for commercialization, using pond ash, which is difficult to recycle.

\section{Experimental Procedure}

Figure 1 shows the experimental procedure of this study. In this study, pond ash collected from the coal ash landfill of a domestic CFPP was used. To remove moisture, the collected pond ash samples were dried in an electric furnace at a constant temperature of $105^{\circ} \mathrm{C}$ for $24 \mathrm{~h}$. Representative samples of pond ash to be use for characteristics analysis were obtained by crushing the collected pond ash samples with a steel rod and then applying a cone-and-quartering sampling method. ${ }^{16)}$

The particle size distribution of pond ash was analyzed using a dry sieving method. To be more specific, about $500 \mathrm{~g}$ of pond ash was sorted using a Ro-Tap sieve shaker (Rx-29, W.S. TYLER ${ }^{\circledR}$, US) for five minutes by allowing it to pass through a series of sieves with mesh sizes of 0.5, 0.3, 0.2, $0.15,0.10,0.07,0.06$, and $0.04 \mathrm{~mm}$. Dry sieving was performed to remove impurities and unburned carbon, using a sieve with a mesh size of $0.06 \mathrm{~mm}$. The content of unburned carbon was analyzed using a thermogravimetric analyzer (TGA 701, Leco Corp., US). Pond ash that has been dried, crushed, but not refined is hereinafter referred to as the "unsieved pond ash" while pond ash that has been dried, crushed, and dry sieved with a $0.06 \mathrm{~mm}$ sieve is hereinafter referred to as the " $0.06 \mathrm{~mm}$ or smaller pond ash." The latter only contains particles no larger than $0.06 \mathrm{~mm}$.

X-ray diffraction analysis was performed using a D8 Advance diffractometer (Bruker-AXS, Germany) to analyze the crystallographic properties of the pond ash according to particle size. Diffraction patterns were obtained over a range of $5-100^{\circ} 2 \theta$ with a step size of $0.01^{\circ}$, and the scanning speed was 1 second per step. Qualitative analysis was carried out using DIFFRAC.EVA V4.2 (Bruker-AXS, Germany) and PDF-2 Release 2016 (ICDD, US). Also, to analyze the content of the crystalline phases and amorphous substances, quantitative X-ray diffraction analysis was carried out in the same analytical conditions. Quantitative analysis was performed with DIFFRAC.PLUS TOPAS4.2 (Bruker-AXS, Germany) using a Partial Or NO Known Crystal Structures (PONKCS) method ${ }^{17)}$ where an unknown (a)

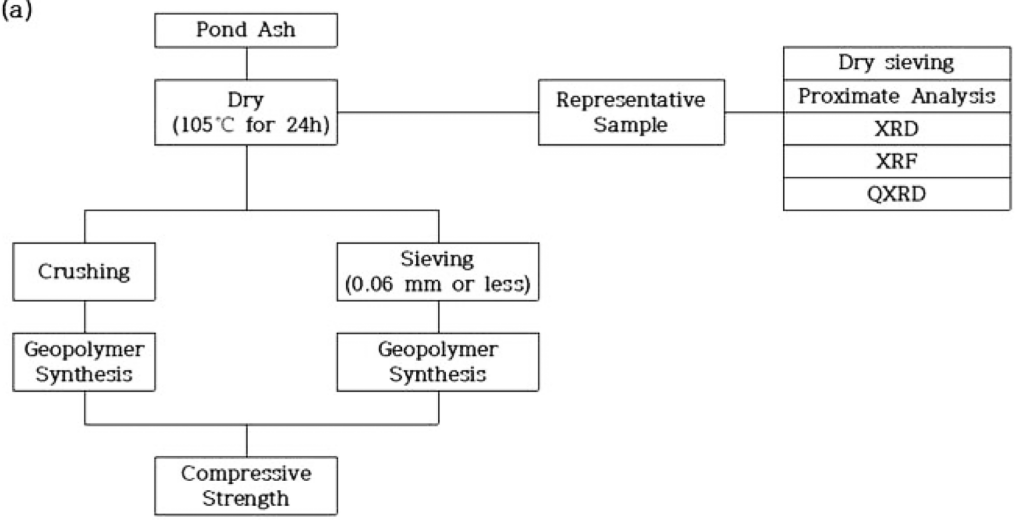

(b)

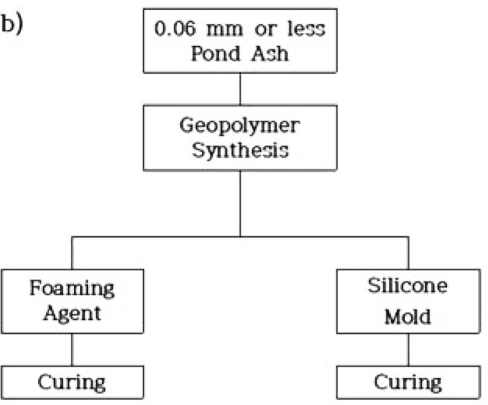

Fig. 1. (a) Experimental procedure, (b) synthetic basalt production procedure. 
mineral phase is defined to have a virtual crystal structure, and based thereon, other mineral phases that are mixed with the unknown phase are quantitatively analyzed using a Rietveld method. $3.0000 \mathrm{~g}$ of pond ash and $0.3333 \mathrm{~g}$ of fluorite $\left(\mathrm{CaF}_{2}\right.$, Alfa Aesar, UK, 99.985\%) as a standard substance were mixed with $8 \mathrm{ml}$ of ethanol and then ground in a McCrone micronizer for five minutes. By doing so, the effects of different X-ray absorption rates and particle size could be minimized. Also, the same analysis was conducted on standard samples $\left(\mathrm{LaB}_{6}, \mathrm{SRM} 660 \mathrm{~b}\right.$, NIST, US) to calibrate the effects of the devices. The chemical composition of the pond ash samples was analyzed using an X-ray fluorescence spectrometer (Shimadzu Sequential XRF-1800, Shimadzu, Japan), and the reactive $\mathrm{Si} / \mathrm{Al}$ ratio of the samples was calculated based on the method ${ }^{18)}$ proposed by Williams and Riessen (2010). As a result, the proper mix proportions for the geopolymers were determined.

The fabricated geopolymer samples were labeled $\mathrm{R}$ or $\mathrm{S}$, depending on whether the used pond ash had been refined or not. $\mathrm{R}$ refers to the geopolymer samples fabricated using the unsieved pond ash, while $\mathrm{S}$ refers to the ones made of the $0.06 \mathrm{~mm}$ or smaller pond ash (Table 1 ). The mix proportions of these geopolymer samples were determined to set the $\mathrm{Si} / \mathrm{Al}$ ratio to $1.5,2.0$, and 3.2 while the $\mathrm{Na} / \mathrm{Al}$ ratio was set to 1.0 , and the content of mixing water was maintained at $20 \%$ (Table 1). Also, to assess the effect of enhanced strength, a specific mix proportion, i.e., an $\mathrm{Si} / \mathrm{Al}$ ratio of 3.2 , an $\mathrm{Na} / \mathrm{Al}$ ratio of 1.0 , and the mixing water content of $18 \%$, was employed to fabricate a geopolymer sample (Table 1). To fabricate geopolymers with $\mathrm{Si} / \mathrm{Al}$ ratios of 1.5 and 2.0, sodium aluminate $\left(\mathrm{NaAlO}_{2}\right.$, Junsei Chemical, $\mathrm{Na}_{2} \mathrm{O} 38.0 \sim$ $\left.42.0 \mathrm{wt} \%, \mathrm{Al}_{2} \mathrm{O}_{3} 51.0 \sim 55.0 \mathrm{wt} \%\right)$ and caustic soda $(\mathrm{NaOH}$, sodium hydroxide, Junsei Chemical, Japan, with a purity of $97.0 \mathrm{wt} \%$ or above) were used as alkali activators. Sodium aluminate was added in powder form and dry mixed with pond ash. The calculated amount of caustic soda was mixed with distilled water and stirred for $24 \mathrm{~h}$ before being added to the mixture of sodium aluminate and pond ash.

To fabricate geopolymers with a $\mathrm{Si} / \mathrm{Al}$ ratio of 3.2 , a

Table 1. Formulation of Geopolymers Using Unsieved Pond Ash $(\mathrm{R}-1,2,3)$ and $0.06 \mathrm{~mm}$ or Smaller Pond Ash (S$1,2,3,4)$

\begin{tabular}{ccccc}
\hline $\begin{array}{c}\text { Sample } \\
\text { name }^{1)}\end{array}$ & $\begin{array}{c}\mathrm{Si} / \mathrm{Al} \\
\text { ratio }\end{array}$ & $\begin{array}{c}\mathrm{Na} / \mathrm{Al} \\
\text { ratio }\end{array}$ & $\begin{array}{c}\text { Water } \\
\text { content } \\
(\%)\end{array}$ & Curing scheme \\
\hline $\mathrm{R}-1$ & 1.5 & & & \\
$\mathrm{R}-2$ & 2.0 & & & \\
$\mathrm{R}-3$ & 3.2 & 1.0 & 20 & $70^{\circ} \mathrm{C}$ for $1 \mathrm{~d}+\mathrm{RT}$ for $6 \mathrm{~d}$ \\
$\mathrm{~S}-1$ & 1.5 & & & \\
$\mathrm{~S}-2$ & 2.0 & & & \\
$\mathrm{~S}-3$ & 3.2 & & & \\
\hline $\mathrm{S}-4$ & 3.2 & 1.0 & 18 & $70^{\circ} \mathrm{C}$ for $1 \mathrm{~d}+\mathrm{RT}$ for $6 \mathrm{~d}$ \\
\hline
\end{tabular}

${ }^{1)} \mathrm{R}$ : unsieved pond ash, S: $0.06 \mathrm{~mm}$ or smaller pond ash

${ }^{2)} \mathrm{RT}$ : Room temperature, d: day or days sodium silicate aqueous solution $\left(\mathrm{Na}_{2} \mathrm{SiO}_{3} \mathrm{H}_{2} \mathrm{O}\right.$, Youngil Chemical, Korea, $\mathrm{SiO}_{2} 32.10 \mathrm{wt} \%, \mathrm{Na}_{2} \mathrm{O} 12.5 \mathrm{wt} \%$ ) and caustic soda were used as alkali activators. The calculated amounts of sodium silicate aqueous solution and caustic soda were mixed and stirred for $24 \mathrm{~h}$ before being used. The mixing process was conducted using a $5 \mathrm{~L}$ mixer (Kenwood mixer, Kenwood Kitchen Appliances, UK). Mixing was performed at a low-speed mode for 2 minutes and a high-speed mode for 5 minutes. The fabricated geopolymer mixtures were poured into cylindrical plastic molds with a diameter of $29 \mathrm{~mm}$ and a height of $58 \mathrm{~mm}$. As a result, four geopolymer specimens for each mix proportion were manufactured. When pouring these geopolymer mixtures into the molds, a compact vibrator (Denstar-500, Denstar, Korea) was used to remove air bubbles trapped during the mixing. The geopolymer specimens were cured in an electric furnace with a constant temperature of $70^{\circ} \mathrm{C}$ for $24 \mathrm{~h}$ and then kept at room temperature. On the seventh day after the mixing, the specimens were demolded. Each demolded specimen was polished with sandpaper to ensure that the ratio of its diameter to height was set to $1: 2$, and its top and bottom planes were parallel while being perpendicular to its sides. The 7-day compressive strength of each geopolymer specimen was measured using a compressive strength test machine (MTS 815, MTS, USA). For each mix proportion, four specimens were measured according to KS F 2405 (Standard Test Method for Compressive Strength of Concrete), and the average compressive strength was calculated.

Geopolymer samples intended for the fabrication of the synthetic basalt were manufactured using pond ash with a particle size of $0.06 \mathrm{~mm}$ or smaller while setting the $\mathrm{Si} / \mathrm{Al}$ ratio to $3.2, \mathrm{Na} / \mathrm{Al}$ ratio to 1.0 , and the content of mixing water to $18 \%$. The mixing process was conducted using a 50 $\mathrm{L}$ mortar mixer. Mixing was performed at a low-speed mode for 5 minutes and at a high-speed mode for 10 minutes. The synthetic basalt was fabricated in two ways: by adding a foaming agent to the geopolymer mixtures and by placing the geopolymer mixtures in a silicon mold. Aluminum powder (Goodfellow, UK, with a purity of $99.9 \%$ ) was used as a foaming agent. The foaming agent was added to the geopolymer mixtures that had gone through the high-speed mixing process with an amount that corresponds to 0.05 $\mathrm{wt} \%$ of the total mixture weight. The mixtures were then subjected to low-speed mixing for 30 seconds to ensure that the added foaming agent was dispersed. Following that, the mixtures were poured into metal molds with dimensions of $100 \times 100 \times 400 \mathrm{~mm}$. To fabricate a silicone mold that has the same bubble patterns on the surface as natural basalt, an outdoor decorative lamp was fabricated using natural basalt and dismantled so that it could be molded with silicone. The silicone film was then peeled off (Fig. 2). After the high-speed mixing process, the geopolymer mixtures were poured into the silicone mold to fill nearly $90 \%$ by volume of each mold. Once poured into the mold, the synthetic basalt samples were sealed to prevent the occurrence of efflores- 

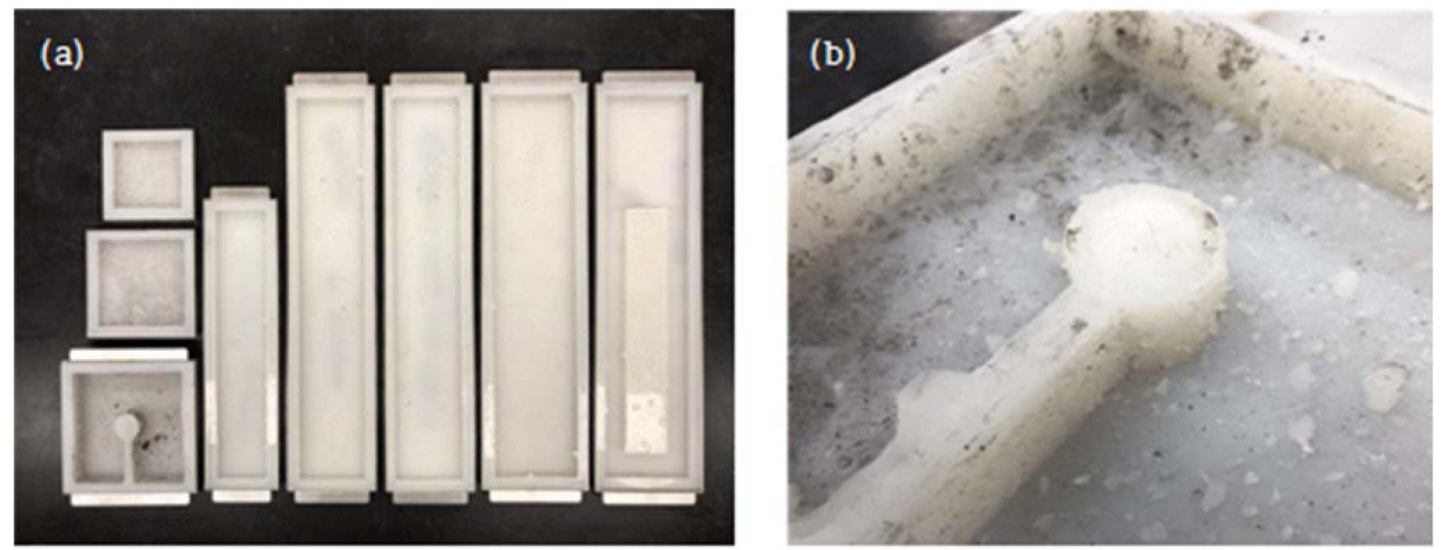

Fig. 2. (a) Silicone molds used for synthetic basalt production, (b) protrusions for expressing the porosity.
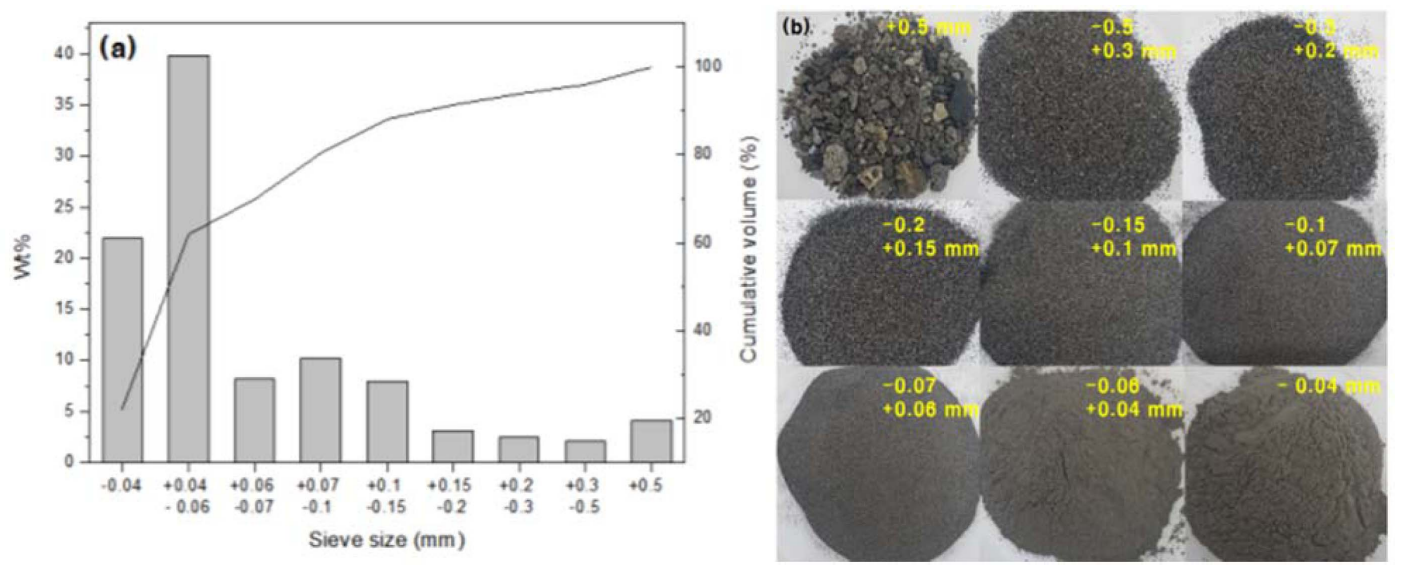

Fig. 3. Dry sieve analysis results of the unsieved pond ash (a) and photos (b). $0.06 \mathrm{~mm}$ or smaller pond ash accounted for about $62 \%$ of total pond ash. Pond ash was mainly black due to unburned carbon but $0.06 \mathrm{~mm}$ or smaller pond ash was light gray.

cence and cured in an electric furnace for $24 \mathrm{~h}$ at $70^{\circ} \mathrm{C}$ and for another $24 \mathrm{~h}$ at $90^{\circ} \mathrm{C}$.

\section{Results and Discussion}

\subsection{Characteristics of Pond Ash}

Dry sieving of the pond ash was performed, and as a result, it was determined that nearly $4 \%$ of its particles were $0.5 \mathrm{~mm}$ or larger, which fell into the largest size group and contained various-sized impurities, such as bottom ash, unburned coal, and soil (Fig. 3). Particles no larger than $0.06 \mathrm{~mm}$ accounted for $62 \%$, the largest portion (Fig. 3(a)). Here, the pond ash appeared black due to unburned carbon, but the $0.06 \mathrm{~mm}$ or smaller particles were light brown (Fig. $3(b))$. The larger the particles were, the higher the portion of unburned carbon was, and the darker the color of coal ash became. ${ }^{19-21)}$ Unburned carbon has been known to negatively affect the geopolymer reaction ${ }^{20-22)}$ by adsorbing part of the alkali activator ${ }^{23)}$ and thus increasing the content of mixing water. Kang et al. (2013) reported a slight increase in the compressive strength of geopolymers when made of coal ash from which unburned carbon had been removed using an air classification method. ${ }^{20)}$ Alternative ways of removing unburned carbon include sieve analysis, triboelectrostatic separation, froth flotation, and agglomeration methods. ${ }^{24)}$ In this study, a sieve analysis method was employed. The method was capable of removing unburned carbon and reducing the particle size of coal ash through simple processes. This is because smaller coal ash particles are more quickly dissolved by alkali activator, ${ }^{23)}$ thereby accelerating the geopolymer reaction.

Industrial chemical analysis results indicated that the content of unburned carbon in the unsieved pond ash was $3.61 \%$. In contrast, in the $0.06 \mathrm{~mm}$ or smaller pond ash, unburned carbon was not detected.

X-ray diffraction analysis of each particle size group of pond ash revealed that all particle size groups contained various crystalline phases, such as mullite, quartz, cristobalite, calcite, rutile, maghemite, hematite, and halite (Fig. 4). Kim et al. (2018) reported that in fly ash domestically used as a cement admixture, crystalline phases, including mullite, quartz, maghemite, calcite, hematite, and rutile, were detected. ${ }^{11)}$ Here, the halite originated from the combination of $\mathrm{Na}^{+}$and $\mathrm{Cl}^{-}$in the coal ash and existed on the sur- 


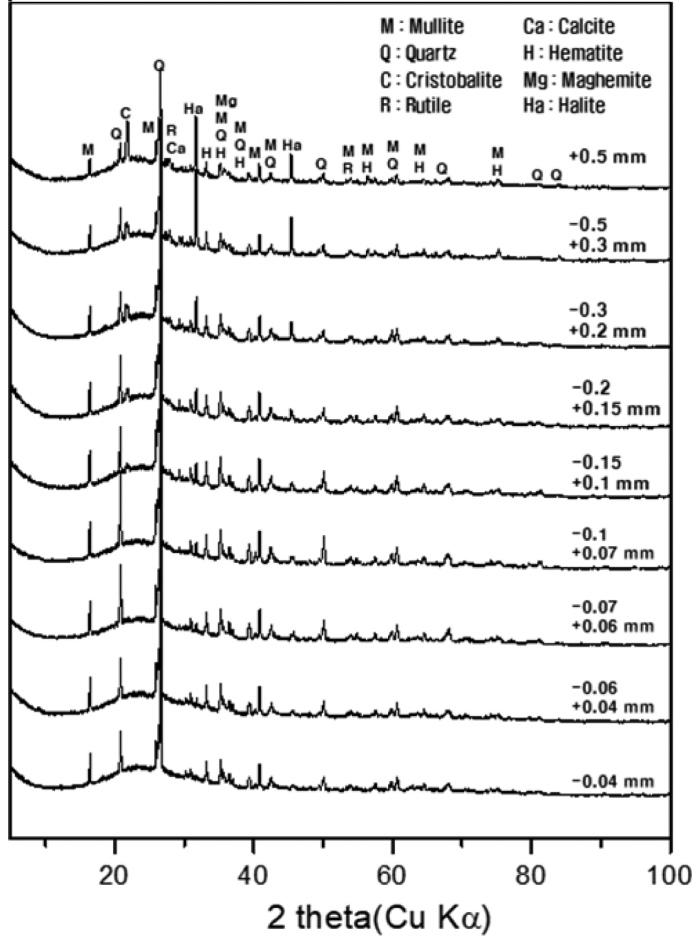

Fig. 4. Results of X-ray diffraction analysis by particle size. Some crystalline phases are present in the pond ash. There was no difference in the type of crystalline phase depending on particle size. face of the coal ash in the form of inorganic chloride. ${ }^{25)}$

$\mathrm{X}$-ray fluorescence analysis results indicated that in both the unsieved pond ash and the $0.06 \mathrm{~mm}$ or smaller pond ash, the combined content of $\mathrm{SiO}_{2}, \mathrm{Al}_{2} \mathrm{O}_{3}$, and $\mathrm{Fe}_{2} \mathrm{O}_{3}$ was not less than $70 \%$, and the content of $\mathrm{CaO}$ was less than $7 \%$ (Table 2). Thus, it was confirmed that the pond ash above fell into Class F Fly Ash under ASTM C618. Meanwhile, in the $0.06 \mathrm{~mm}$ or smaller pond ash, the ignition loss was about $4.7 \%$, and the figure was about $1.5 \%$ lower than that in the unsieved pond ash (Table 2).

Quantitative X-ray diffraction analysis results showed that the content of crystalline phases, such as mullite, quartz, and cristobalite, was lower in the $0.06 \mathrm{~mm}$ or smaller pond ash than in the unsieved pond ash. In contrast, the content of other crystalline phases, including calcite, rutile, maghemite, hematite, and halite, as well as amorphous substances, was higher in the $0.06 \mathrm{~mm}$ or smaller pond ash than in the unsieved pond ash (Fig. 5). Previous studies have reported that when sieved, coal ash ended up with a lower content of crystalline mullite and quartz, while the content of amorphous substances increased. ${ }^{23)}$ This is because kaolin contained in coal turns into crystalline mullite and quartz through dehydroxylation and calcination reactions during the coal combustion process, but when the particle size becomes small, coal ash cools down more quickly, providing little time for kaolin to

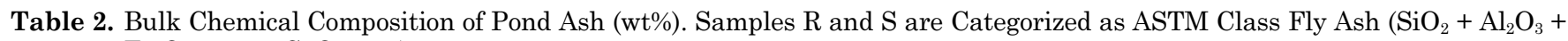
$\left.\mathrm{Fe}_{2} \mathrm{O}_{3} \geq 70 \%, \mathrm{CaO}<7 \%\right)$

\begin{tabular}{cccccccccccc}
\hline Sample & $\mathrm{SiO}_{2}$ & $\mathrm{Al}_{2} \mathrm{O}_{3}$ & $\mathrm{Fe}_{2} \mathrm{O}_{3}$ & $\mathrm{CaO}$ & $\mathrm{MgO}$ & $\mathrm{K}_{2} \mathrm{O}$ & $\mathrm{Na}_{2} \mathrm{O}$ & $\mathrm{TiO}_{2}$ & $\mathrm{MnO}$ & $\mathrm{P}_{2} \mathrm{O}_{5}$ & Igloss \\
\hline $\mathrm{R}$ & 53.87 & 20.70 & 6.79 & 5.76 & 2.13 & 1.02 & 0.99 & 1.16 & 0.08 & 0.77 & 6.19 \\
$\mathrm{~S}$ & 53.48 & 21.40 & 7.33 & 5.97 & 2.33 & 1.14 & 1.02 & 1.22 & 0.08 & 0.83 & 4.71 \\
\hline
\end{tabular}

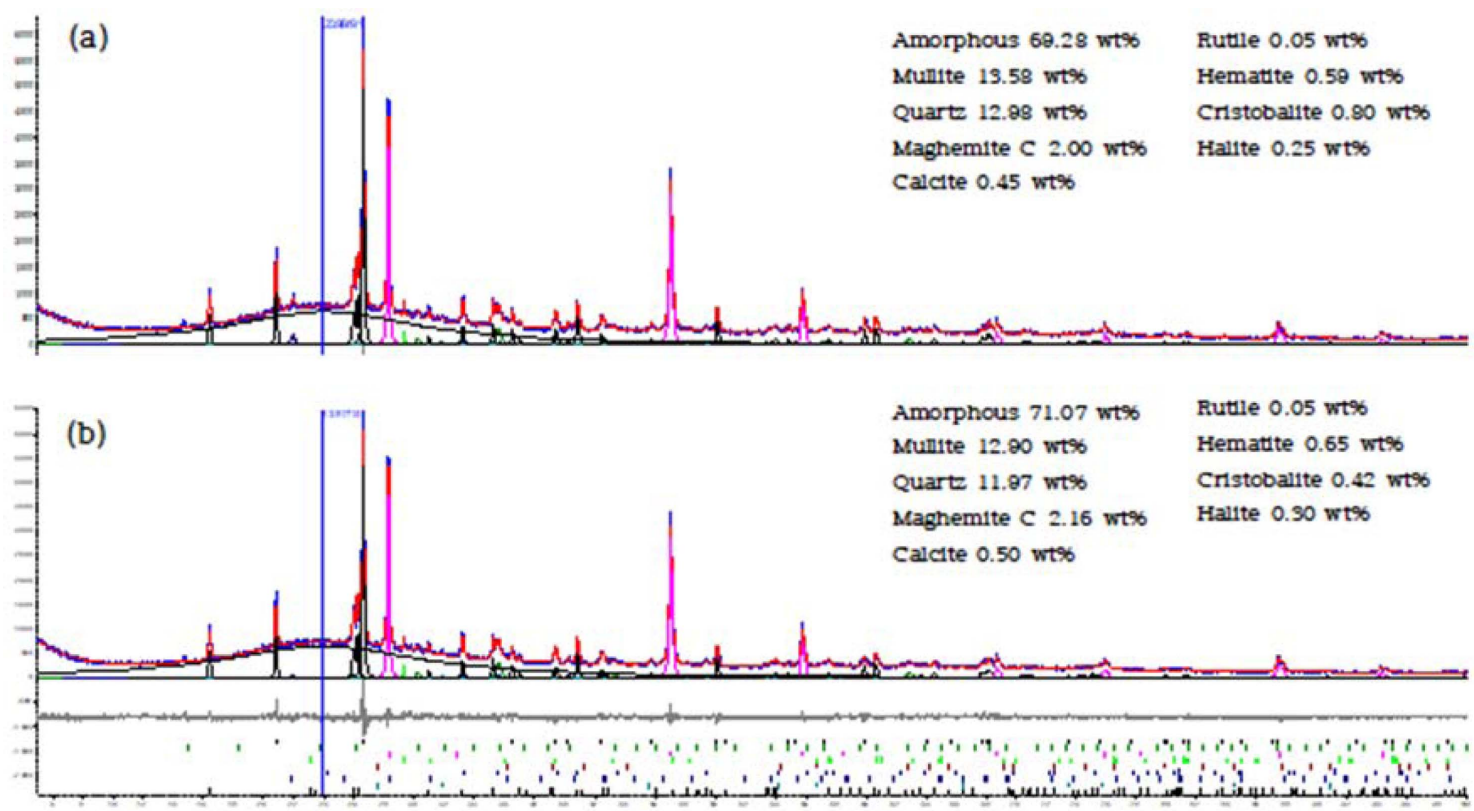

Fig. 5. X-ray diffraction pattern of unsieved pond ash (a) and $0.06 \mathrm{~mm}$ or smaller pond ash (b) for quantitative Rietveld analysis of crystalline and amorphous phases. The content of amorphous substance and four crystalline phases (maghemite, calcite, hematite, and halite) in the $0.06 \mathrm{~mm}$ or smaller pond ash was higher than in unsieved pond ash. 
Table 3. Amorphous Composition of Pond Ash Used in This Study (wt\%). The Reactive Si/Al Ratio of Samples R and S were Determined to be 2.93 and 2.71, Respectively

\begin{tabular}{ccccccccccccc}
\hline Sample & $\mathrm{SiO}_{2}$ & $\mathrm{Al}_{2} \mathrm{O}_{3}$ & $\mathrm{Fe}_{2} \mathrm{O}_{3}$ & $\mathrm{CaO}$ & $\mathrm{MgO}$ & $\mathrm{K}_{2} \mathrm{O}$ & $\mathrm{Na}_{2} \mathrm{O}$ & $\mathrm{TiO}_{2}$ & $\mathrm{MnO}$ & $\mathrm{P}_{2} \mathrm{O}_{5}$ & $\begin{array}{c}\mathrm{Si} / \mathrm{Al} \\
(\mathrm{molar})\end{array}$ \\
\hline $\mathrm{R}$ & 36.60 & 10.61 & 4.25 & 5.51 & 2.13 & 1.02 & 0.86 & 1.11 & 0.08 & 0.77 & 2.93 \\
$\mathrm{~S}$ & 37.78 & 11.81 & 4.58 & 5.69 & 2.33 & 1.14 & 0.87 & 1.17 & 0.08 & 0.83 & 2.71 \\
\hline
\end{tabular}

transform into crystalline phases. It thus remains as amorphous $\mathrm{SiO}_{2}$-based substances. ${ }^{23)}$ For that reason, the smaller the coal ash particle size is, the higher the content of amorphous substances it contains.

Meanwhile, based on the results of the X-ray fluorescence analysis and quantitative X-ray diffraction analysis, the reactive $\mathrm{Si} / \mathrm{Al}$ ratio was calculated according to the method proposed by Williams and Riessen (2010) ${ }^{18)}$ as follows: 2.93 for the unsieved pond ash and 2.71 for the $0.06 \mathrm{~mm}$ or smaller pond ash (Table 3).

\subsection{Characteristics of Compressive Strength of Geo- polymers Made of Pond Ash}

The average 7-day compressive strength of the geopolymer samples made of the unsieved pond ash when setting the $\mathrm{Na} / \mathrm{Al}$ ratio to 1.0 and the content of mixing water to

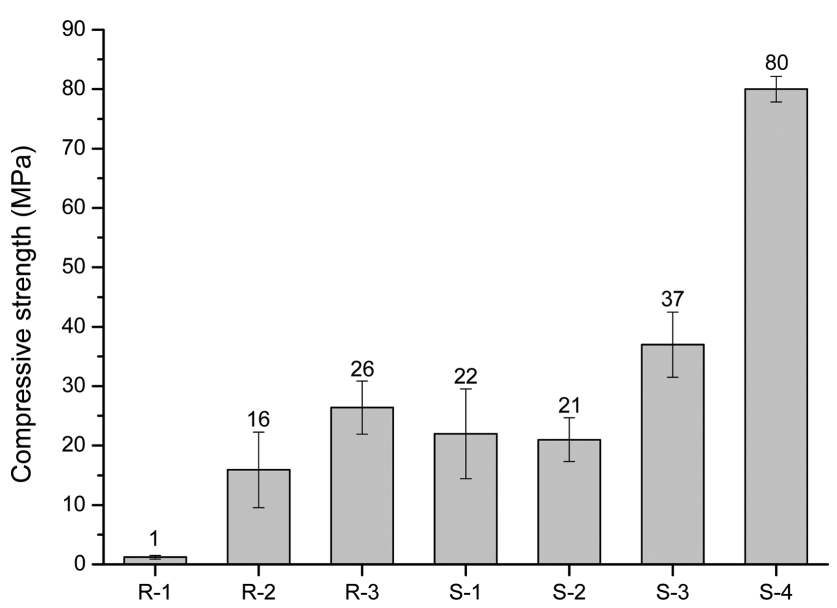

Fig. 6. 7-day compressive strength of unsieved pond ashbased geopolymers (R-1, 2, 3) and $0.06 \mathrm{~mm}$ or smaller pond ash-based geopolymers (S-1, 2, 3, 4). Higher strength was developed by geopolymers having $18 \%$ water content (S-4).
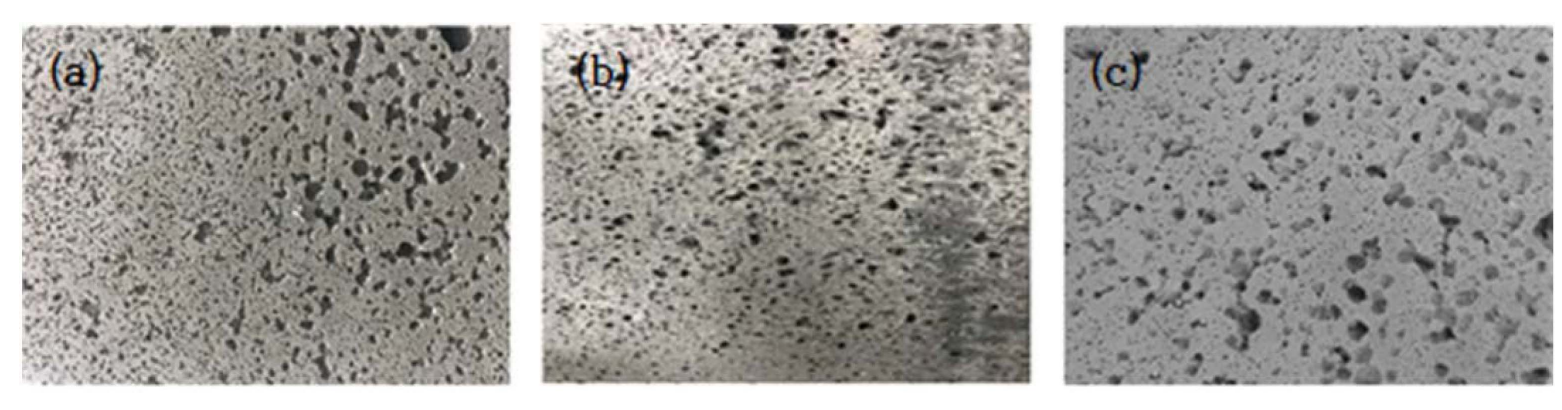

Fig. 7. Surface of the natural basalt (a), synthetic basalt made using foaming agent (b), and synthetic basalt made using a silicone mold (c).
$20 \%$ was found to increase with the increasing $\mathrm{Si} / \mathrm{Al}$ ratio (Fig. 6). The average 7-day compressive strength was highest, at $26 \mathrm{MPa}$, when the $\mathrm{Si} / \mathrm{Al}$ ratio was 3.2 (R-3) (Fig. 6). In contrast, the average 7-day compressive strength of the geopolymer samples made of the $0.06 \mathrm{~mm}$ or smaller pond ash while setting the $\mathrm{Na} / \mathrm{Al}$ ratio to 1.0 and the content of mixing water to $20 \%$ was found to be comparable to the strengths achieved when the $\mathrm{Si} / \mathrm{Al}$ ratio was 1.5 (S-1) and 2.0 (S-2), i.e., $22 \mathrm{MPa}$ and $21 \mathrm{MPa}$, respectively (Fig. 6). The average 7-day compressive strength was highest at $37 \mathrm{MPa}$ when the $\mathrm{Si} / \mathrm{Al}$ ratio was $3.2(\mathrm{~S}-3)$. The figure was even higher than that measured from the R-3 specimen made of the unsieved pond ash when setting the $\mathrm{Si} / \mathrm{Al}$ ratio to 3.2 (Fig. 6). Regardless of the Si/Al ratio, the compressive strengths were higher in the specimens made of the 0.06 mm or smaller pond ash (S-1, 2, and 3) than in the specimens made of the unsieved pond ash (R-1, 2, and 3). This was considered to be due to the combined effect of the reduced content of unburned carbon, the decreased pond ash particle size, and the increased content of reactive amorphous substances during the sieving process.

Within the experimental scope of this study, the compressive strengths were higher in the specimens with the higher $\mathrm{Si} / \mathrm{Al}$ ratio (R-3 and $\mathrm{S}-3$ ) than in the specimens with the lower $\mathrm{Si} / \mathrm{Al}$ ratio (R-1, $\mathrm{R}-2, \mathrm{~S}-1$, and $\mathrm{S}-2)$. It is worth noting that the specimens with the lower $\mathrm{Si} / \mathrm{Al}$ ratio were fabricated using sodium aluminate as an alkali activator, and thus there were more aluminum atoms, which may substitute silicon in the silicate tetrahedron when the $\mathrm{Si} / \mathrm{Al}$ ratio is lower. As a result, the total number of silicate tetrahedrons, which have a strong bonding structure, i.e., by mesodesmic bonds, ${ }^{26)}$ decreased while the number of aluminum tetrahedrons, which are deficient in positive charges, increased. Despite the contribution of network modifiers, such as sodium, supplementing the deficiency in positive charges, the geopolymer reaction cannot fully take place,

\author{
-
}


and thus part of those aluminum tetrahedrons may remain deficient of charges. Furthermore, part of the network modifiers tends to combine with oxygen to form non-bridging oxygens, thereby degrading the overall connectivity of the network structure. ${ }^{27)}$ When the $\mathrm{Si} / \mathrm{Al}$ ratio is lower, the content of aluminum is higher, and thus more network modifiers are needed, and more non-bridging oxygens are thought to be formed in the specimens with the lower $\mathrm{Si} / \mathrm{Al}$ ratio. Simply put, in the specimens with the lower $\mathrm{Si} / \mathrm{Al}$ ratio, the total number of silicate tetrahedrons was lower, and thus more non-bridging oxygens could be formed, presumably resulting in the lower compressive strengths.

The S- 4 specimen was fabricated using the same mix proportion as in the S-3 specimen whose average 7-day compressive strength was the highest, except that the content of mixing water was reduced by $2 \%$. The average 7 -day compressive strength of S-4 was determined to be $80 \mathrm{MPa}$, which was nearly 2.2 times higher than that of S-3, where the content of mixing water was higher (Fig. 5). Vora et al. (2013) also reported a similar observation, that the reduced content of mixing water led to an increase in the compressive strength of the geopolymers, and this phenomenon has similarly been observed in cement. ${ }^{28)}$ In geopolymers, mixing water serves as a medium to facilitate the dissolution of aluminosilicate materials and thus promote the geopolymer reaction. ${ }^{29)}$ The addition of excessive mixing water causes the relative content of the alkali activator to decrease, thus reducing the concentration of the alkali activator. When the concentration of an alkali activator is low, it is known that the dissolution of aluminosilicate materials and the hydrolysis process - the first phase of the geopolymer reactionmay be limited, ${ }^{30)}$ and therefore the geopolymer reaction will be hindered. In this regard, it is considered that adding the minimum amount of mixing water necessary to ensure sufficient flowability in the mixing process will contribute to increasing the compressive strength of the resulting geopolymers.

In this study, the geopolymer pastes made solely of pond ash and alkali activator exhibited high-strengths depending on the chemical composition and the content of mixing water, i.e., the average 7-day compressive strength was up to $80 \mathrm{MPa}$. In the case of cement, high-strength aggregate should be used to produce high-strength concrete. In addition, It is necessary to minimize the water-cement ratio using superplasticizer and to densify the microstructure of the cement paste with a cement binder such as silica fume. ${ }^{31,32)}$ However, fabricating a geopolymer only requires the mixing of pond ash and alkali activator, and thus its manufacturing process is simpler than that of cement concrete. Also, pond ash disposed of in landfills is used as the main raw material, and therefore it is possible to consume a large amount of pond ash in landfills, thereby contributing to reducing pond ash dust.

3.3. Characteristics of Synthetic Basalt Made of Pond Ash-based Geopolymers
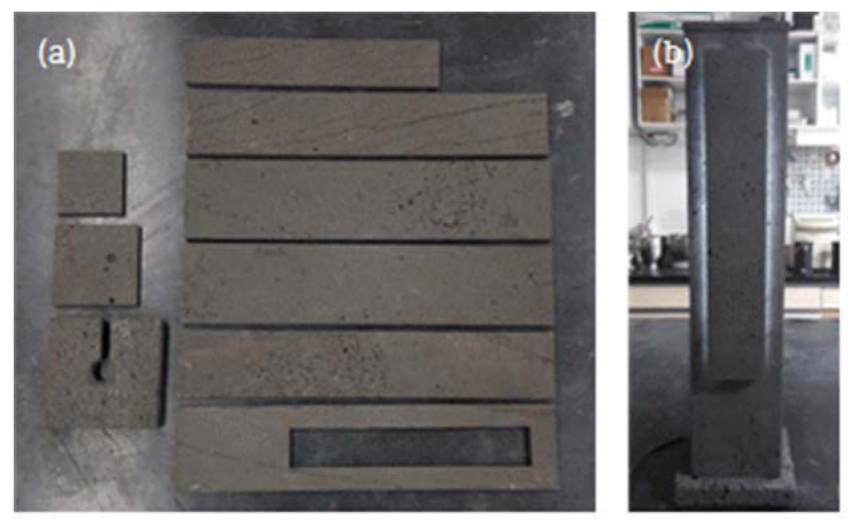

Fig. 8. Geopolymer-based synthetic basalts made by molding (a) and outdoor standing lamp made with geopolymer-based synthetic basalts (b).

Small and large blow holes were observed on the surface of the synthetic basalt specimens that were fabricated by adding a foaming agent to geopolymers, as occurs in natural basalt (Fig. 7(b)). Also, black bands were visible all over the surface, which represented the presence of unburned carbon. This was because unburned carbon, which is relatively light, floated to the surface along with the gases that were released with the addition of the foaming agent (Fig. 7(b)). Lee et al. (2016) fabricated lightweight porous geopolymer samples by adding aluminum powder to geopolymers and found that the average 7-day compressive strength of those porous geopolymers was only 6 to $18 \%$ that of solid geopolymers. ${ }^{13)}$ Although in this study, the compressive strength of the foaming agent-added geopolymer samples was not measured, it was fairly predictable that their compressive strength would be lower than that of their solid counterparts.

In the meantime, the black bands were not detected on the surface of the synthetic basalt specimens that were fabricated by placing the geopolymer mix in silicone molds. The size of the blow holes and surface patterns were found to be the same as those for the natural basalts that was used to fabricate those silicone molds (Fig. 7(c), Fig. 8(a)). These fabricated synthetic basalt specimens were then assembled using Araldite adhesive to make an outdoor standing lamp, which precisely resembled the original natural basalt lamp (Fig. 8(b)). These results confirm that to fabricate synthetic basalt products that have the same appearance as their natural basalt counterparts, the method of placing geopolymers in a silicone mold is more advantageous than the method of adding a foaming agent to the geopolymers.

In current synthetic basalt products, specific pigments are added to make them look like natural basalt. But while the addition of pigments may make them look similar to natural basalt for a time, discoloration may occur over time. In contrast, synthetic basalt products made of pond ash-based geopolymers tend to appear dark grey, and thus there is no need to add any pigments. This means that it is possible to fabricate synthetic basalt products that have the same sur- 
face pattern and color as natural basalt simply by mixing pond ash with an alkali activator.

\section{Conclusions}

Mineralogical and chemical characteristics of pond ash collected from the landfill of a domestic coal-fired power plant were analyzed quantitatively and the amounts of reactive amorphous $\mathrm{SiO}_{2}$ and $\mathrm{Al}_{2} \mathrm{O}_{3}$ were calculated. Based on these results, mix proportions of geopolymers were determined. The Si/Al ratio was set to $1.5,2.0$, and 3.2 while the $\mathrm{Na} / \mathrm{Al}$ ratio and the content of mixing water were fixed. The average 7-day compressive strength of the geopolymer samples made of the unsieved pond ash was found to increase with the increasing $\mathrm{Si} / \mathrm{Al}$ ratio, and the figure was highest at $26 \mathrm{MPa}$ when the $\mathrm{Si} / \mathrm{Al}$ ratio was 3.2. For the geopolymer samples made of $0.06 \mathrm{~mm}$ or smaller pond ash, from which unburned carbon had been removed, the average 7-day compressive strength was highest, at $37 \mathrm{MPa}$, when the $\mathrm{Si} / \mathrm{Al}$ ratio was 3.2. Notably, decreasing the content of mixing water by $2 \%$ significantly increased the average 7 -day compressive strength to $80 \mathrm{MPa}$. Based on these results, removing unburned carbon from pond ash, as well as adding the minimum amount of mixing water necessary to ensure sufficient flowability in the mixing process, will likely contribute to increasing the compressive strength of the resulting geopolymers. To fabricate geopolymer-based synthetic basalt products that have the same bubble patterns as their natural basalt counterparts, a method of placing geopolymers in a silicone mold was more advantageous than a method of adding a foaming agent to geopolymers. Unsieved pond ash can be processed into low-strength geopolymer products, and when sieved, they can be used to fabricate high-strength geopolymer products without being mixed with aggregates. Also, it is possible to fabricate synthetic basalt products that have the same appearance as natural basalt and are strong enough to be commercialized. Therefore, it is expected to contribute to promoting the mass consumption and recycling of pond ash.

\section{Acknowledgments}

This study has been carried out as part of the research project funded by Korea Western Power (Project name: Production of Coal Ash-Based Non-Sintering Artificial Basalt for Limitless Recycling of Coal Ash), and their support is deeply appreciated.

\section{REFERENCES}

1. J. H. Maeng, T. Y. Kim, and D. H. Seo, "Minimizing Environmental Impact in accordance with the Thermal Power Plant Ash Management(I)," Korea Environment Institute, 2014.

2. T.-W. Jeon, J.-E. Park, D.-G. Hwang, S.-Y. Hong, S.-K. Shin, G.-J. Oh, Y.-Y. Kang, N.-I. Um, Y.-W. Jeong, and S.
K. Jeong, "The Study on Recycling Availability and Use Expansion of Coal Ash," National Institute of Environmental Research, 2014.

3. Y. H. Kim, "Manufacture of Lightweight Aggregates Using Bottom Ash," J. Rec. Const. Resources, 11 [2] 30-4 (2016).

4. S. Lee, S. Cho, Y. S. Lee, E. M. An, and S. B. Cho, "Application of Unburned Carbon Produced from Seochun Power Plant,” J. Korean Inst. Resour. Recycl., 23 [1] 40-7 (2014).

5. Y. Kim, K. Kim, and G. Y. Jeong, "Study of Detailed Geochemistry of Hazardous Elements in Weathered Coal Ashes," Fuel, 193 343-50 (2017).

6. D. H. Kim, W. S. Ki, and S. H. Kim, "The Utilization of Pond Ash as Embankment and Backfill Material," J. Engineering Geology, 20 [3] 297-310 (2010).

7. J. Temuujin, A. Minjigmaa, B. Davaabal, T. Zolzaya, U. Bayarzul, T. Jadambaa, and C. H. Rüscher "Preparation of Geopolymer-Type Mortar and "Light-Weight Concrete" from Coppoer Flotation Waste and Coal Combustion by Products," pp. 89-101 in Developments in Strategic Ceramic Materials: A Collection of Papers Presented at the 39th International Conference on Advanced Ceramics and Composites, John Wiley \& Sons, USA 2016.

8. J. Temuujin, A. Minjigmaa, U. Bayarzul, D. S. Kim, S.-H. Lee, H. J. Lee, C. H. Ruescher, and K. J. D. MacKenzie, "Properties of Geopolymer Binders Prepared from Milled Pond Ash," Mater. Construcc., 67 [328] e134 (2017).

9. M. Panigrahi, S. Mohanty, R. R. Dash, and R. I. Ganguly, "Development of Novel Constructional Material from Industrial Solid Waste as Geopolymer," IOP Conf. Ser.: Mater. Sci. Eng., 410 [1] 012012 (2018).

10. S Lee, H. T. Jou, C. M. Chon, N. H. Kang, and S. B. Cho, "Developing and Assessing Geopolymers from Seochun Pond Ash with a Range of Compositional Ratios," J. Korean Ceram. Soc., 50 [2] 134-41 (2013).

11. B. Kim, Y.-E. Heo, C. M. Chon, and S. Lee, "Influence of $\mathrm{Na} / \mathrm{Al}$ Ratio and Curing Temperature of Geopolymers on Efflorescence Reduction," J. Korean Inst. Resour. Recycl., 27 [6] 59-67 (2018).

12. S. Lee, A. Van Riessen, and C. M. Chon, "Benefits of Sealed-Curing on Compressive Strength of Fly Ash-based Geopolymers," Materials, 9 [7] 598 (2016).

13. S. Lee, E. M. An, and Y. H. Cho, "Effect of Foaming Agent Content on the Apparent Density and Compressive Strength of Lightweight Geopolymers," JRCR, 4 [4] 36370 (2016).

14. Y. N. Lee, and I. S. Jung, "Boundary Stone Made from Artificial Basalt," Korea Patent, 20-2001-0031178, 2011.

15. S. H. Shin and M. K. Jo, "Artifical Stone Made from Waste Stone or Lightweight Aggregate of Baslt," Korea Patent, 10-2012-0059758, 2012.

16. M. C. Fuerstenau and K. N. Han, Principles of Mineral Processing; p. 573, Society for Mining, Metallurgy, and Exploration Inc, USA, 2003.

17. C. M. Chon, S. Lee, and S. W. Lee, "Quantitative X-ray Diffraction Analysis of Synthetic Mineral Mixtures Including Amorphous Silica using the PONKCS Method," J. Miner. Soc. Korea, 26 [1] 27-34 (2013).

18. R. P. Williams and A. Van Riessen, "Determination of the Reactive Component Fly Ashes for Geopolymer Produc- 
July 2019 Compressive Strength Properties of Geopolymers from Pond Ash and Possibility of Utilization as Synthetic Basalt 373

tion Using XRF and XRD," Fuel, 89 [12] 3682-92 (2010).

19. I. Külaots, R. H. Hurt, and E. M. Suuberg, "Size Distribution of Unburned Carbon in Coal Fly Ash and its Implications," Fuel, 83 [2] 223-30 (2004).

20. N. H. Kang, C. M. Chon, H. T. Jou, and S. Lee, "Effect of Particle Size and Unburned Carbon Content of Fly Ash from Hadong Power Plant on Compressive Strength of Geopolymers," Korean J. Mater. Res., 23 [9] 510-16 (2013).

21. S. Lee, M. D. Seo, Y. J. Kim, H. H. Park, T. N. Kim, Y. Hwang, and S. B. Cho, "Unburned Carbon Removal Effect on Compressive Strength Development in a Honeycomb Briquette Ash-based Geopolymer," Int. J. Miner. Process., 97 [1-4] 20-25 (2010).

22. J. Davidovits, M. Izquierdo, X. Querol, D. Antennuci, H. Nugteren, V. Butselaar-Orthlieb, C. Fernández-Pereira, and Y. Luna, The European Research Project GEOASH: Geopolymer Cement Based On European Coal Fly Ashes; Geopolymer Institute Library, Technical Paper, 22, 2014.

23. A. Van Riessen and N. Chen-Tan, "Beneficiation of Collie Fly Ash for Synthesis of Geopolymer: Part 1-Beneficiation," Fuel, 106 569-75 (2013).

24. S. Lee, S. Cho, Y. S. Lee, E. M. An, and S. B. Cho, "Application of Unburned Carbon Produced from Seochun Power Plant," J. Korean Inst. Resour. Recycl., 23 [1] 40-7 (2014).

25. D. N. C. Phan, The Relationship between Fly Ash Chem- istry and the Thermal Formation of Polychlorinated Pollutants during Waste Incineration, pp. 60-1, in Ph.D. Thesis, Umeå universitet, Umeå, 2013.

26. C. Klein and A. R. Philpotts, Earth Materials: Introduction to Mineralogy and Petrology; pp. 66-72, Cambridge University Press, Cambridge, 2013.

27. H. Schmidt and H. Scholze, In Aerogels; The Sol-Gel Process for Non-Metallic Inorganic Materials; pp. 49-56, Springer, Berlin, 1986.

28. P. R. Vora and U. V. Dave, "Parametric Studies on Compressive Strength of Geopolymer Concrete," Procedia Eng., 51 210-19 (2013).

29. S. Park and M. Pour-Ghaz, "What is the Role of Water in the Geopolymerization of Metakaolin?," Constr. Build. Mater., 182 360-70 (2018).

30. Z. Zuhua, Y. Xiao, Z. Huajun, and C. Yue, "Role of Water in the Synthesis of Calcined Kaolin-based Geopolymer," Appl. Clay Sci., 43 [2] 218-23 (2009).

31. T. W. Kong, S. H. Lee, C. W. Kwon, and H. B. Lee, "Advanced Concrete Technology Trends," Ceramist, 14 [6] 45-53 (2011).

32. S. W. Kim, S. T. Kang, and S. M. Han, "Characteristics and Application of Ultra High Performance Cementitious Composite," Magazine of the Korea Concrete Institute, 18 [1] 16-21 (2006) 